\title{
Implimentasi Sistem Bunga dan Bagi Hasil Terhadap Kinerja Keuangan Perbankan
}

\author{
Surhaman Amin \\ Dosen Jurusan Syariah Sekolah Tinggi Agama Islam Negeri \\ Sorong Papua Barat \\ surahman.amin74@gmail.com
}

\begin{abstract}
This research is aimed to know difference of the financial performance of the conventional banking and the syariah banking. Financial is measured by using ratios: ratio of capital to asset deliberated by according to risk, ratio of earning asset which classified to earning asset (KAP. I), ratio of allowance for possible earning losses to classified earning asset ( KAP.II), ratio of net operating income to operating income (NPM) representing proxy from management, ratio of profit before interest and tax to total asset ( $R O A$ ), ratio of operating expenses to operating income (BOPO), ratio of current assets to current liabilities and ratio of loan to deposit (LDR). This research use the saturated simple, that all bank of state of the public ownerships (BUMN) and bank of the Muamalat Indonesia, by using data of the secondary publicized by the Bank Indonesia each of semester, between period 2003-2011. The analysis instruments used was Multivariate Discriminant Analysis (MDA). Results of this research indicate that the CAMEL approach can determine banking financial performance. Pursuant to statistical test really there was financial performance difference between conventional banking and syariah banking, where conventional banking has
\end{abstract}


better finance performance from syariah banking. This research found that CAR dan LDR; significantly differentiate conventional banking finance performance and syariah banking, in which the CAR was the most dominant.

Keywords: Capital, Assets, Management, Equity and Liquidity.

\section{Pendahuluan}

Berbagai penelitian telah dilakukan untuk menilai kinerja suatu usaha dengan menggunakan rasio keuangan. Dengan menganalisis rasio-rasio keuangan suatu usaha, akan dapat memprediksi kinerja suatu usaha. Analisis rasio-rasio keuangan seringkali membuat salah untuk menginterprestasikan dan membingungkan, rasio keuangan yang mana yang paling dominan. Untuk melengkapi analisis tersebut dapat menggunakan tehnik analisis statistik yang tepat sesuai dengan tujuan penelitian. Altman (1968) dengan judul penelitian Financial Ratio, Discriminant Analysis And The Prediction of Corporate Bankruptc, dengan analisis Multiple Discriminant Analysis (MDA). Berdasarkan metode tersebut dihasilkan nilai Z-Score yang menunjukkan indikator kebangkrutan perusahaan. Dengan titik cutt-of yang memisahkan perusahaan yang bankrut dan tidak, adalah 1,81. Dari hasil penelitian tersebut dapat memprediksikan kebankrutan perusahaan dengan tingkat ketepatan sebesar 94 persen. Penelitian yang senada juga dilakukan Sinkey (1975), menggunakan multiple discriminant analysis. Dalam penelitian tersebut ditemukan, bahwa rasio keuangan signifikan berbeda antara perusahaan perbankan yang bermasalah dan yang tidak bermasalah untuk periode 4 tahun sebelum bank mengalami masalah.

Penelitian dengan menggunakan rasio keuangan untuk memprediksi kinerja pada perbankan telah dilakukan oleh Whalen dan Thomson (1988), yang berjudul Using Financial Data to Identify Change in Bank Condition, dengan menggunakan metode analisis Logit Re-gression ditemukan, bahwa CAMEL secara akurat dapat digunakan untuk menentukan rating bank di Amerika Serikat dan Non Performing Loans 
and Primary/ Lease Capital yang merupakan proksi Asset Quality merupakan prediktor yang terbaik $(90,9 \%)$ dalam menentukan rating bank.

Sumarta dan Yogiyanto (2000), dalam penelitiannya, Evaluasi Kinerja Perusahaan Perbankan antara Indonesia dengan Thailand yang terdaftar di bursa efek Indonesia dan Thailand sebelum krisis tahun 1997, dengan periode penelitian 1994-1996. Pendekatan CAMEL digunakan sebagai proksi kinerja perbankan, yang terdiri dari: CAR as represent of capital, RORA as represent of assets quality, NPM as represent of management, ROA dan BOPO as represent of earning, CML dan KDN as represent of Liquadity, Hasilnya mengindikasikan, bahwa rata-rata kinerja perbankan di Indonesia lebih baik dari pada di Thailand. Dimana, CAR, RORA, ROA, CML, dan KDN secara statistik mempunyai perbedaan yang signifikan dari kedua negara tersebut. Dari jumlah skor CAMEL, mengindikasikan kinerja perbankan Indonesia dan Thailand mempunyai perbedaan yang signifikan, dimana kinerja perbankan Indonesia lebih baik dari kinerja perbankan Thailand. Selanjutnya, penelitian yang berjudul Modeling Monetary Stablity Under Banking System: The Case Of Malaysia, oleh Kaleem (2001). Tujuan dari penelitian ini, adalah untuk menilai stabilitas dan efisiensi dari instrumen moneter Islam dalam dual banking. Penelitian dilaksanakan di Malaysia, karena Malaysia menerapkan dual banking secara simultan dan mengalami krisis keuangan, yaitu pada periode 1994 sampai 1999. Dari penelitian tersebut menemukan bahwa, instrumen moneter Islam lebih stabil dari instrumen moneter yang konvensional.

Penelitian senada, oleh Tlemsani dan Matthews (2002), dengan judul penelitian Ethical Banking Islamic House Financing in The United Kingkom: A Comparative Study. Penelitian ini adalah bagian dari studi dari peran Islamic Finance dalam sektor keuangan global modern. Dalam penelitian tersebut, membuktikan bahwa sistem Islam lebih stabil dan transparan, sehingga dapat diadobsi keseluruh dunia.

Perbedaan-perbedaan prinsip tentunya mempunyai dampak terhadap kinerja perbankan, antara perbankan konvensional dan perbankan syariah. Kondisi perekonomian yang mulai stabil juga akan sangat mem- 
pengaruhi kinerjanya. Justru pada keadaan seperti ini, kedua sistem (konvensional dan syariah) tersebut akan teruji, sistem mana yang mempunyai ketahanan lebih, yang diwujudkan oleh kinerja keuangan perbankan. Oleh sebab itu peneliti ingin mengkomparasikan kinerja keuangan perbankan konvensional dan syariah.

Berdasarkan uraian dan alasan tersebut di atas, peneliti ingin mendapatkan gambaran tentang kinerja perbankan konvensional dan syariah dari aspek keuangan. Berdasarkan uraian pada latar belakang, maka perumusan masalah dalam penelitian ini adalah sebagai berikut:

1. Variabel-variabel apa saja yang menentukan kinerja keuangan perbankan konvensional dan syariah.

2. Apakah ada perbedaan kinerja keuangan perbankan konvensional dengan syariah.

3. Variabel manakah yang mendominisasi perbedaan kinerja keuangan perbankan konvensional dengan syariah.

\section{Signifikansi Penelitian}

Berdasarkan pada latar belakang dan rumusan masalah yang dikemukakan diatas, maka penelitian ini bertujuan untuk:

1. Menjelaskan variabel-variabel yang menentukan kinerja keuangan perbankan konvensional dan syariah.

2. Menjelaskan dan menganalisis perbedaan kinerja keuangan perbankan konvensional dengan syariah.

3. Menjelaskan dan menganalisis variabel-variabel yang mendominasi perbedaan kinerja keuangan perbankan konvensional dan syariah

\section{Metode Penelitian}

\section{Populasi dan Sampel Penelitian}

Populasi dalam penelitian ini adalah seluruh bank konvensional yang berbadan hukum BUMN (Badan Usaha Milik Negara) dan seluruh bank syariah yang telah memberikan laporan keuangan ke Bank Indo- 
nesia (BI) selama periode 2003 sampai 2009. Jumlah bank keseluruhan 6 buah, untuk bank konvensional dan 3 buah bank syariah, antara lain: BNI, BII, BL,BMI,BSM dan BSMI.

Jumlah sampel yang akan diambil sebanyak 6 bank atas dasar ketersediaan data sesuai dengan periode penelitian yang diperlukan, yaitu tahun 2005 sampai 2015. Karena jumlah populasi sama dengan sampel/ sampel jenuh, maka penarikan data dilakukan dengan metode sensus. Sensus adalah suatu survey dimana informasi yang dikumpulkan dari semua anggota populasi atau kelompok yang dipelajari (Arikonto, 1998).

\section{Sumber dan Tehnik Pengumpulan data}

Sumber data yang digunakan dalam penelitian ini adalah dokumen yang diperoleh dari bank Indonesia (data sekunder) yang berupa laporan keuangan persemester dari tahun 2003 sampai 2009, dengan tehnik pengumpulan data, tehnik dokumentasi. (Arikonto, 1998)

\section{Analisis Diskriminan}

Penggunaan analisis diskriminan dimaksud untuk mengelompokkan suatu observasi baik secara kualitatif maupun statistik dapat dibedakan dengan jelas. Menurut Joseph F Flair et a!. (1981) analisis diskriminan terdiri dari tiga tahap yaitu: pertama, Tahap derivasi, tahap ini terdiri dari: a. Menentukan variabel bebas (Variabel Pembeda). b. Menentukan variabel tergantung (Nilai Diskriminan). c. Penghitungan koefisien variabel pembeda. Melakukan uji statistik. Kedua, Tahap Validasi. Pada tahap ini terdapat beberapa pertimbangan yang perlu mendapat perhatian, antara lain: a. Mengembangkan pengklasifikasian Matrik. b. Menentukan cutting scor. c. Membentuk pengklasifikasian matri. d. Chance Model. e. Pengklasifikasian keakuratan relatif dan perubahan.

\section{Tahap Interpretasi}

Adapun maksud dan tujuan tahap ini, adalah memberikan arti dan 
hasil yang diperoleh. Beberapa hal yang perlu mendapat perhatian dalam tahap ini antara lain:

a. Koefisien diskriminan (Discriminant Coeficient)

b. Struktur hubungan (Discriminant Loading)

c. Nilal F Parsial.

\section{Difinisi Operasional}

Difinisi operasional dari masing-masing variabel adalah sebagai berikut:

\section{Variabel terikat}

Variabel terikat dalam penelitian ini adalah Kinerja bank, yang merupakan salah satu tolok ukur yang digunakan untuk mengukur prestasi atau kondisi bank.

\section{Variabel Bebas}

a. Permodalan. Sedangkan Aktiva Tertimbang Menurut Resiko (ATMR) merupakan bobot resiko yang didasarkan pada kadar resiko yang terkandung pada aktiva. Rasio permodalan adalah perbandingan Modal terhadap Aktiva Tertimbang Menurut Resiko (ATMR).

b. Kualitas Aktiva Produktif. Penilaian dilakukan dengan menggunakan rasio-rasio: 1. Rasio aktiva produktif yang diklasifikasikan terhadap aktiva produktif. 2. Rasio penyisihan penghapusan aktiva produktif yang dibentuk terhadap penyisihan aktiva produktif yang wajib dibentuk.

c. Manajemen. Manajemen akan diproksikan dengan Net Profit Margin, yaitu rasio pendapatan operasional bersih terhadap pendapatan operasional.

d. Rentabilitas. Penilaian rentabilitas ada dua macam penilaian, yaitu: Return of Assets adalah perbandingan antara laba kotor 
tehadap total aktiva Rasio antara biaya operasional dengan pendapatan operasional.I

e. Likuiditas. Untuk menghitung rasio ini digunakan rasio sebagai berikut: Rasio kredit terhadap dana yang diterima (loan to deposit ratio)

\section{Hasil Dan Pembahasan Deskripsi Variabel Penelitian}

Berikut ini akan diuraikan masing-masing variabel penelitian dalam suatu tabel group statistik yaitu rata-rata dari masing-masing variabel bebas perbankan konvensional dan syariah.

Tabel 1.

Gambaran Variabel Bebas kedua Kelompok Perbankan/ Group Statistik.

\begin{tabular}{|c|l|l|l|}
\hline \multicolumn{2}{|c|}{ KINERJA } & \multicolumn{1}{|c|}{ Mean } & Std. Deviation \\
\hline .00 & CAR & 12.7914 & 3.23556 \\
& KAP 1 & 1.3762 & 1.36575 \\
& KAP 2 & 78.3338 & 44.99344 \\
& NPM & 11.5157 & 5.71159 \\
& ROA & 1.7167 & .75109 \\
& BOPO & 75.3648 & 19.19059 \\
& LDR & 85.8529 & 8.17091 \\
\hline \multirow{1}{*}{1.00} & CAR & 18.9438 & 4.25226 \\
& KAP 1 & 2.4314 & 1.82176 \\
& KAP 2 & 114.0576 & 30.85851 \\
& NPM & 19.8914 & 7.24518 \\
& ROA & 2.0010 & .94092 \\
& BOPO & 83.8233 & 7.10161 \\
& LDR & 65.9833 & 16.24532 \\
\hline
\end{tabular}

Keterangan:

$00=$ adalah perbankan syariah

$01=$ adalah perbankan konvensional 


\section{Capital Adequacy Ratio (CAR).}

Berdasarkan tabel 11. dapat diketahui bahwa rata-rata CAR perbankan konvensional sebesar 18.9438 dan 12.7914 untuk perbankan syariah. Dengan demikian CAR perbankan syariah lebih kecil dari perbankan konvensional, yang berarti rata-rata CAR perbankan konvensional lebih baik. Artinya modal perbankan syariah lebih solvabel dari perbankan konvensional.

\section{Kualitas Aktiva Produktii (KAP I).}

Dari tabel 11 dapat diketahui, bahwa rata-rata perbankkan konvensional $2.4314 \%$ dan $1.3762 \%$ untuk bank syariah. Artinya rata-rata setiap Rp. 1 aktiva produktif dialokasikan atau diinvestasikan mengandung resiko sebesar 2,4\% untuk perbankan konvensional dan 1,4\% untuk perbankan syariah.

Menurut ketentuan Bank Indonesia batas maksimal sebesar 15,5 $\%$, dengan demikian perbankan konvensional lebih baik dari pada perbankan syariah. Artinya perbankan syariah banyak mengalokasikan dananya atau aktiva produktifnya kepada usaha-usaha dengan tingkat resiko yang lebih besar dari perbankan konvensional.Tingkat resiko ini akan menentukan kualitas aktiva produktif. Dengan kata lain ratarata kualitas aktiva produktif perbankan konvensional lebih baik dari perbankan dari kualitas perbankan syariah.

\section{Kualitas Aktiva Produktii (KAP II ).}

Dari tabel. 11. dapat diketahui, rata-rata besarnya KAP II untuk perbankan konvensional sebesar $114.05 \%$ dan $78.33 \%$ untuk perbankan syariah. Meskipun sama-sama diatas $100 \%$, tetapi perbankan syariah lebih kecil. Artinya perbankan konvensional mempunyai cadangan yang lebih besar dari perbankan syariah dalam menutupi kemungkinan terjadinya kerugian atau penurunan aktiva. 


\section{Manajemen(Net Profit Margin/NPI ).}

Dari tabel. 11 dapat diketahui rata-rata NPM bank konvensional sebesar 19.89 \% lebih besar dari NPM syariah sebesar $11.51 \%$. Artinya rata-rata perbankan konvensional mampu melaksanakan manajemen umum dan resiko lebih baik dari perbankan syariah. Hal ini dapat dilihat 20\% dari pendapatan operasional menjadi pendapatan operasional bersih (laba bersih). Kebalikannya, perbankan syariah hanya memperoleh pendapatan operasional bersih sebesar $12 \%$ dari pendapatan operasional. Semakin besar besar rasio ini, berarti semakin baik kualitas manajemennya, begitu juga sebaliknya semakin kecil rasio ini, berarti semakin kurang baik kualitas manajemennya dalam mengelola bank secara keseluruhan.

\section{Return 0n Assets (R0A ).}

Dari tabel 11 dapat diketahui, bahwa rata-rata ROA perbankan konvensional sebesar $20 \%$ dan $17 \%$ untuk perbankan syariah. Hal ini berarti perbankan syariah mempunyai kemampuanyang lebih dalam menghasilkan keuntungan dari total aktiva yang dimiliki, apabila dibandingkan dengan perbankan konvensional.

\section{Biaya Operasional terhadap Pendapatan 0perasional (B0P0).}

Dari tabel. 11 dapat diketahui, rata-rata BOPO untuk perbankan konvensional sebesar $83.82 \%$. Artinya setiap Rp 1 pendapatan operasional memerlukan biaya operasional sebesar Rp. 0,83. Sedangkan rata-rata BOPO perbankan syariah sebesar $75.36 \%$ artinya perbankan syariah dalam mengoperasionalkan usahanya memerlukan biaya operasional lebih besar dari perbankan konvensional untuk memperoleh pendapatan operasional. Artinya setiap Rp.1 pendapatan operasional memerlukan biaya operasional sebesar Rp 0,75. Hal ini mengindikasikan bahwa perbankan syriah lebih efisien dalam operasional.

Loan to Deposit Ratio ( LDR ). Dari tabel 11 rata-rata LDR perbankan konvensoinal sebesar $65.9833 \%$ dan $85.8529 \%$ untuk perbankan 
syariah, sedangkan batas aman ratio ini sebesar 85\%-100\%. Dengan demikian posisi LDR perbankan syariah dalam posisi rawan untuk macet. Perbankan konvensional rata-rata LDRnya sangat sehat dan aman dalam memenuhi kebutuhan dana. Artinya tidak semua dana dari masyarakat disalurkan kembali melalui pemberian kredit, hanya $66 \%$ dana dari masyarakat yang disalurkan kembali. Berbeda dengan perbankan syariah, rata-rata semua dana yang dihimpun, disalurkan kembali kepada masyarakat. Meskipun demikian perbankan syariah lebih berani ekpansi usahanya atau permintaan akan dana lebih besar dari pada perbankan konvensional.

\section{Pengujian Hipotesis}

\section{Pengujian Hepotesis Pertama}

Hipotesis pertama menyatakan bahwa variabel CAR, Kualitas Aktiva, Manajemen, Rentabilitas dan Likuiditas berpengaruh dalam menentukan perbedaan kinerja keuangan perbankan konvensional dan syariah. Berdasarkan analisis diskriminan dengan metode langsung dapat diketahui hubungan antara variabel pembeda atau bebas dengan variabel terikat serta seberapa besar dari variabel terikat dapat dijelaskan oleh variabel pembeda dapat dilihat dari hasil Canonical Corelation. Dari hasil perhitungan menunjukkan nilai Canonical Corelation sebesar 0,810 mendekati 1,00 berarti kedelapan variabel bebas atau pembeda mempunyai hubungan yang kuat dalam menentukan perbedaan kinerja keuangan perbankan konvensional dengan perbankan syariah.

Besarnya kemampuan variabel pembeda (Kedelapan variabel) terhadap nilai diskriminan dapat dilihat dari nilai Uji chi - Squere sebesar 38.955 dengan taraf signifikan: 0,00. Hal ini menunjukkan, bahwa variabel pembeda dapat mempengaruhi perbedaan kinerja keuangan perbankan konvensional dengan perbankan syariah sebesar $39 \%$, sedangkan $61 \%$ dipengaruhi oleh faktor lain diluar variabel yang tidak diuji dalam penelitian ini. Sedangkan untuk mengukur variasi variabel 
terikat yang dapat dijelaskan oleh variabel bebas dalam suatu model, yang dapat dilihat dari koefisien determinan atau di sebut Fit Model.

Besarnya Fit Model bergerak antara $0-1(0<\mathrm{R} 2<1)$. Nilai koefisien ini diperoleh dengan mengkuadratkan nilai Canonical Corelation jadi besarnya R2 : $38 \%$. Berdasarkan analisis diskriminan dengan metode langsung dapat diketahui nilai koefisien dari fungsi diskriminan standart (SCDFC) dari kedelapan variabel pembeda berperan dalam menentukan perbedaan kinerja keuangan perbankan konvensional dengan perbankan syariah. Adapun model persamaannya sebagai berikut:

$$
\begin{aligned}
\mathrm{Z}= & -0,304+0,133 \mathrm{X} 1-177 \mathrm{X} 2+0,012 \mathrm{X} 3+0,068 \mathrm{X} 4-0,179 \mathrm{X} 5+ \\
& 0,008 \mathrm{X} 6-0,53 \mathrm{X} 7 .
\end{aligned}
$$

Dari perhitungan nilai Hit Ratio $>\mathrm{C}$ max $>$ Pro membuktikan, bahwa Pengklasifikasian kinerja keuangan perbankan konvensional dengan perbankan syariah sangat akurat. Dimana variabel pembeda mempunyai pengaruh dalam membedakan kinerja keuangan kedua kelompok perbankan tersebut.

Dari uraian tersebut dapat disimpulkan, bahwa variabel CAMEL secara simultan terbukti secara nyata mempunyai pengaruh dalam menentukan perbedaan kinerja keuangan perbankan konvensional dengan perbankan syariah. Dengan demikian hipotesa pertama diterima.

Keadaan ini sesuai dengan hasil penelitian Sinkey (1975) dengan menggunakan MDA menunjukkan bahwa semua variabel secara nyata atau signifikan menentukan perbedaan kinerja keuangan perbankan. Begitu juga didikung oleh hasil penelitian Purbawangsa (1998), Irianto (1998), Witohrocmi (2000). Budiono (2001) membuktikan, bahwa semua variabel (CAEL) dengan metode MDA secara nyata menentukan perbedaan kinerja keuangan perbankan. Begitu juga dengan Budiono (2001) bahwa variabel CAMEL dengan metode MDA membuktikan hal yang sama. 


\section{Pengujian Hipotesis Kedua}

Untuk menguji kebenaran hipotesis kedua yang menyatakan bahwa ada perbedaan kinerja keuangan perbankan konvensional dengan perbankan syariah, menggunakan MDA dengan metode langsung. Wilks Lamda pada prinsifnya untuk mengetahui varians total dalam skore diskriminan yang tidak dijelaskan oleh perbedaan antara kedua kelompok perbankan. Dengan Wilks Lamda sebesar 0,344 dan Chi-Squre sebesar 38.955 dengan tingkat signifikan 0,00 menunjukkan, bahwa ada perbedaan yang nyata antara kinerja keuangan perbankan konvensional dengan syariah. Dengan demikian hipotesa kedua diterima.

Hasil temuan ini sejalan dengan temuan Amrizal (1995), bahwa ada perbedaan kinerja keuangan antara perbankan konvensional dengan syariah, dimana kinerja keuangan perbankan syariah lebih baik dari konvensional. Penelitian tersebut dilaksanakan pada periode 19921995 (Sebelum krisis ekonomi).

Selama krisis ekonomi keadaan kinerja perbankan syariah menunjukkan perkembangan yang meningkat (Budiono, 2001). Hal ini disebabkan karena perbankan syariah tidak mengalami resiko fluktuasi tingkat suku bunga, resiko yang dihadapi perbankan syariah lebih terfokus pada resiko likuiditas dan resiko kredit (Arifin,1999). Sebanyak 63 bank konvensional ditutup yang diakibatkan oleh semakin menurunnya pendapatan dari bunga, yang pada akhirnya berakibat adanya negative spread. Keadaan ini akan berdampak pada menurunnya kemampuan modal untuk menutup segala resiko, yang tercermin dari besarnya CAR yang negative atau dibawah $8 \%$.

Untuk mengatasi keadaan tersebut, diperlukan restrukturisasi perbankan sebagai upaya membangun kembali perekonomian, maka dibentuklah BPPN yang mengemban misi membantu penyehatan sektor perbankan secara keseluruhan sehingga mengarah kesektor perbankan yang sehat sejalan dengan standar Bank for International Settlements (BIS). Dengan program tersebut keadaan kinerja perbankan konvensional akan semakin baik / sehat. 
Kondisi krisis ekonomi yang berdampak pada krisis perbankan dapat dijadikan pelajaran bagi dunia perbankan, terutama bagi perbankan konvensional untuk meningkatkan managemen resiko. Hal ini dapat dilihat besarnya LDR perbankan konvensional yang relatif lebih kecil dari perbankan syariah. Karena kondisi perekonomian yang belum pulih, maka perbankan konvensional sangat hati-hati dalam menjalankan fungsi intermediasi / penyaluran dana. Apabila besarnya LDR tidak diikuti dengan peningkatan managemen akan berdampak pada menurunnya kualitas aktiva (KAP). Dengan demikian kinerja perbankan konvensional relatif membaik, bahkan lebih baik dari perbankan syariah.

Berbeda dengan perbankan syariah, kondisi krisis justru kepercayaan masyarakat meningkat (tabungan), sehingga pihak bank berusaha untuk menyalurkan dana kepada masyarakat untuk memperoleh yang margin layak. Hal ini dapat dilihat dari besarnya LDR / FDR (Financing to deposite ratio) yang lebih besar dari perbankan konvensional. Besarnya FDR yang besar tidak diikuti dengan managemen (NPM) yang baik, maka akan berdampak pada menurunnya kualitas aktiva. Dengan demikian akan menurunkan kinerja perbankan syariah.

\section{Pengujian Hipotesis ketiga}

Hipotesa ketiga menyatakan, bahwa variabel Manajemen mempunyai kontribusi yang dominan dalam membedakan kinerja keuangan perbankan konvensional dengan syariah. Untuk membuktikan hipotesis ini, maka dilakukan MDA dengan metode stepwise, yaitu pengujian dilakukan secara bertahap untuk masing-masing variabel. Hasil pengujian ini menunjukkan bahwa ada 2 variabel yang secara nyata mempunyai kontribusi dalam membedakan kinerja keuangan perbankan konvensional dan perbankan syariah. Adapun secara berurutan sebagai berikut: CAR dan LDR.

Berdasarkan nilai fungsi dikriminan standar (SCDFC) dapat diketahui besarnya kontribusi dari masing-masing variabel dalam membedakan kinerja keuangan perbankan dengan model persamaan sebagai 
berikut:

$$
Z=0,742 X 1-0,708 X 6
$$

Dari model persamaan tersebut dapat diketahui bahwa variabel CAR yang dominan atau paling besar dalam membedakan kinerja keuangan perbankan konvensional dan perbankan syariah.

Dari penjelasan di atas dapat disimpulkan, bahwa hipotesis yang menyatakan bahwa variabel manajemen mempunyai kontribusi yang dominan atau paling besar sebagai dalam membedakan kinerja keuangan perbankan konvensional dan syariah tidak terbukti, dengan demikian hipotesis ketiga ditolak.

Keadaan ini berbeda oleh hasil penelitian Purbawangsa (1998), dengan metode tidak langsung (stepwise) diperoleh bahwa variabel KAP I yang paling dominan dalam menentukan perbedaan kinerja keuangan perbankan. Penelitian ini juga didukung oleh hasil penelitian Whalen dan Thomson (1988) menggunakan CAMEL dengan metode Logit Regression, ternyata Asset quality merupakan predictor terbaik (90,9 \%) dalam menentukan rating bank Namun bertentangan dengan hasil temua Irianto (1998), Witurocmi (2000) dimana variabel yang dominan adalah manajemen.

Dari beberapa hasil penelitian dapat disimpulkan, bahwa variabel yang dominan antara peneliti yang satu dengan peneliti yang lain ternyata tidak konsinten. Hal ini disebabkan oleh lokasi, objek, waktu dan sistem perbankan yang berbeda.

Dalam penelitian ini objek, waktu dan sistem perbankan berbeda dengan penelitian terdahulu. Dimana pada penelitian terdahulu hanya terfokus pada bank perkreditan rakyat (Bank berskala kecil) yang segmen pasarnya menengah ke bawah (UKM), kondisi perekonomian yang relatif stabil dan pada sistem perbankan yang konvensional saja - Pada penelitian ini objeknya pada perbankan yang berskala besar, kondisi perekonomian belum stabil atau pasca krisis. Dalam penelitian ini, membandingkan perbedaan sistem perbankan konvensional dengan 
perbankan syariah, yang secara prinsip sangat berbeda.

Hasil temuan dalam penelitian ini, ternyata variabel CAR mempunyai kontribusi yang paling besar atau dominan dalam membedakan kinerja keuangan perbankan konvensional dan perbankan syariah. Variabel ini berkenaan dengan kemampuan bank dalam memenuhi kecukupan modal untuk memperoleh keuntungan yang maksimal.

Dengan demikian dapat disimpulkan, bahwa CAR atau kecukupan modal (Dominan) dan LDR yang membedakan perbedaan kinerja keuangan perbankan konvensional dengan perbankan syariah. Setelah krisis ekonomi, perbankan dituntut untuk meningkatkan manajemen resikonya atau menerapkan prinsip kehat-hatian, agar kejadian yang lalu tidak terulang kembali (Krisis perbankan). Hal ini sangat kentara bagi perbankan konvensional dalam menyalurkan dananya ke masyarakat sangat hati-hati. Keadaan ini bisa dilihat dari kecilnya tingkat LDR perbankan konvensional apabila dibandingkan dengan tingkat LDR perbankan syariah. Bagi perbankan syariah yang tidak begitu terpengaruh dengan kondisi krisis, maka tingkat LDRnya lebih besar. Disamping kondisi tersebut diatas. Besarnya tingkat suku bunga bagi perbankan konvensional juga menjadi penghalang bagi masyarakat untuk memperoleh dana pinjaman,karena kondisi perekonomian belum sepenuhnya pulih .Hal ini berdampak pada tingkat LDR perbankan Konvensional.

Berbeda dengan perbankan syariah, yang tidak tergantung dengan tingkat suku bunga, tidak kesulitan dalam menyalurkan dananya. Di samping itu, pengetahuan masyarakat tentang sistem syariah terus meningkat (Banyak perbankan konvensional membuka unit syariah ) dan kondisi perekonomian juga mulai membaik. Dengan bertindak aktif (Optimis) perbankan syariah meningkatkan LDRnya, berbeda dengan perbankan konvensional yang pasif yang selalu menunggu (Trauma). Disatu sisi masyarakat menghendaki kredit, tetapi tingkat suku bunga masih tinggi, berarti perbankan konvensional masih menilai tingkat resiko masih besar (Perekonomian belum sepenuhnya pulih).

Namun besarnya penyaluran dana (LDR) bagi perbankan syariah cukup rawan karena tingkat kualitas aktiva juga besar (KAP I). Arti- 
nya pengalokasian dananya cukup menanggung resiko. KAP I (Assets quality) adalah rasio Aktiva Produktif Yang Diklasifikasikan (APYD) dengan Aktiva produktif. APYD adalah aktiva produktif, baik yang sudah maupun yang mengandung potensi tidak memberikan penghasilan atau menimbulkan kerugian, yang besarnya ditetapkan sebagai berikut:

a. 25\% dari Aktiva Produktif yang digolongkan Dalam Perhatian Khusus;

b. 50\% dari Aktiva Produktif yang digolongkan Kurang Lancar;

c. 75\% dari Aktiva Produktif yang digolongkan Diragukan; dan

d. $100 \%$ dari Aktiva Produktif yang digolongkan Macet.

Berbeda dengan perbankan konvensional yang menerapkan kehatihatian dalam penyaluran dananya, dapat dilihat dari kecilnya tingkat KAP I, artinya dalam menyalurkan dana, perbankan konvensional dengan tingkat resiko yang lebih kecil dari pada perbankan syariah.

\section{Keterbatasan Penelitian}

Penelitian ini masih mempunyai beberapa keterbatasan yang memungkinkan dapat mengurangi kualitas hasil. Keterbatasan tersebut antara lain sebagai berikut:

Populasi dan sampel yang digunakan hanya terbatas pada perbankan milik negara, dan periode waktu tertentu. Untuk menghasilkan kesimpulan yang bersifat umum, diperlukan penelitian lebih lanjut dengan ruang lingkup yang lebih luas.

Penelitian ini hanya terbatas pada pada rasio keuangan yang dipublikasikan dalam menilai kinerja bank, tidak semua ketentuan Bank Indonesia dapat dilakukan dalam menilai kesehatan perbankan.

\section{Penutup}

Berdasarkan hasil analisis dan pembahasan tentang komparasi kinerja keuangan perbankan konvensional dengan, dapat disimpulkan 
sebagai berikut :

Hasil analisis diskriminan dengan metode langsung diperoleh hasil, bahwa kedelapan variabel, yaitu : CAR, KAP I, KAP II, NPM, ROA, BOPO, dan LDR (CAMEL) menentukan kinerja keuangan perbankan konvensional dan syariah.

Hasil analisis diskriminan dengan metode langsung diperoleh hasil, bahwa ada perbedaan kinerja keuangan perbankan konvensional dengan syariah. Sesuai dengan ketentuan Bank Indonesia dalam menilai tingkat kesehatan bank diperoleh hasil, bahwa perbankan konvensional lebih sehat dari syariah.

Hasil analisis diskriminan dengan metode tidak langsung diperoleh hasil, bahwa, Variabel CAR dan LDR yang mempunyai kontribusi dalam membedakan perbedaan kinerja keuangan perbankan konvensional dengan syariah, dengan Variabel CAR yang dominan.

\section{Saran}

Berdasarkan hasil penelitian ini, dapat diperoleh beberapa saran yang dapat dijadikan bahan pertimbangan sebagai berikut:

Bagi pihak perbankan konvensional agar dapat meningkatkan kinerja keuangan dengan meningkatkan LDR yang disertai dengan peningkatan kualitas manajemen, sehingga dapat mempercepat perputaran aktiva, yang pada akhirnya dapat meningkatkan ROA. Bagi pihak perbankan syariah agar dapat meningkatkan kinerja keuangan dengan meningkatkan kualitas manajemen umum, terutama manajemen aktiva produktif, sehingga dapat meningkatkan kualitas aktiva produktif serta menjaga keseimbangan antara likuiditas dan rentabilitas. Bagi peneliti lanjutan, informasi ini dapat digunakan untuk pengembangan lebih lanjut dengan ruang lingkup yang lebih luas. 


\section{Daitar Pustaka}

Abdullah, Faisal. 2003 .Manajemen Perbankan, Teknik Analisis Kinerja keuangan Bank. UMM Press Malang.

Altman, E.I. (1968). Financial Ratio, Disckriminant Analysis And The Prediction of Corporate Bankrupt. Jurnal of Finance (September), p. 589-609.

Amrizal,1995. Analisis Komparatif Laporan Keuangan PT Bank “ X “ sebagai Alat Ukur Kinerja Manajemen Bank Syariah di Indonesia . Tesis Pasca Sarjana IPWI. Jakarta.

Antonio, M. Syafii. 1999. Bank Syariah bagi Bankir \& Praktisi Keuangan. Bank Indonesia dan Taskiah Institute. Jakarta. . 1999. Bank Syariah Wacana Ulama \& Cendikiawan, Bank Indonesia dan Taskiah Institute. Jakarta.

Arikonto, Suharsimi. 1993. Prosedur Penelitian, suatu Pendekatan Praktek. Rineka Cipta. Jakarta

Bank Indonesia, 2003, http://www.bi.go.id 2003. Cetak Biru Perbankan Syariah, http: ///www.bi.go.id

Beim, David O. 2001. What Triggers a Systemic Banking Crisis. Columbia University.

Brighman, Eugene F, dan Gapenshi, Lois C. 1992. Intermediate Financial Management. Fourh Edition The Dryden Press. Florida.

Chapra, M.Umer. 1997. Alqur'an Menuju Sistem Moneter Yang Adil, Dana Bhakti Prima Yasa. Yogyakarta.

Cooper, DR, dan Emory, CW.1996. Business Research Methods. Edisi Ke 5. Richad D. Irwin. Inc. Elen Gunawan (peterjemah). 1996. Metode Penelitian Bisnis,. Erlangga. Jakarta

Hair, Joseph F, et all. 1981. Multivariate Data Analysis. McMillan Publishing Company.New York.

Haron, Sudin dan Norafifah Ahmad.2000. The Effects of Conventional 
Interest Rate and Rate of Profit on Fund Deposit With Islamic Banking System in Malaysia, International Journal of Islamic Financial Service, Vol. No. 4, January-March.

Heru Budianto, Moh. 2001. Analisis Kinerja BPR, Tesis Pasca Sarjana, Universitas Brawijaya Malang.

Indrianto, Nur dan Bambang Supomo.1999. Metodologi Penelitian Untuk Akuntansi dan Manajemen, BPFE, Yogyakarta.

Irianto. 1998. Analisis Variabel Yang Mempengaruhi Kinerja Keuangan Lumbung Kredit Pedesaan (LKP) Di Pulau Lombok, Tesis Pasca Sarjana Universitas Brawijaya, Malang.

Juwita, Himmiyatul AJ. 1997. Analisis Kinerja Keuangan Sebelum dan Sesudah Akuisisi Pada Sektor Perbankan Di Indonesia, Tesis Pasca Sarjana Universitas Brawijaya, Malang.

Kaleem, Ahmad. 2000. Modeling Monetary Stability Under Dual Banking System The Case Of Malaysia, International Journal of Islamic Financial Service, Vol. 2 No. 1

Kompas, 7 Agustus 2003 18 Oktober 2003

Payamta dan Machfoedz, Mas'ud. 1994. Financial Ratio Analysis and The Prediction of Earning Change In Indonesia, KELOLA UGM, September, pp.137-144.

. 1999, Evaluasi Kinerja Perusahaan Perbankan Sebelum dan Sesudah Menjadi Perusahaan Publik Di Bursa Efek Jakarta, Jurnal KELOLA UGM, September, pp.54-69.

Mannan M. Abdul.1995. Islamic Economic Theory And Practice, Terjemahan HM.Shohaji dkk, Teori dan Praktek Ekonomi Islam, Danar Bhakti Wakaf, Yogyakarta.

Marwati, Liza, et all 2001, Interest Rate and Loan Supply : Islamic Versus Conventional Banking System, Jurnal Ekonomi Malaysia, pp. 61-68 
Matthews, Robin. 2002. Ethical Banking Islamic House Financing in The United Kingdom : A Comparative Study. Center for International Business Policy, Kington Hill.

Mulyono, Teguh Pudjo. 1995. Analisis Laporan keuangan Untuk Perbankan, , Anem Kosong Anem, Jakarta.

Muslehuddin, Muhammad. 1990. Sistem Perbankan Dalam Islam, Rineka Cipta, Jakarta.

Nie, Norma H, et all. 1975. Statistic Packages for The Social Science, Second Edition, Mc. Graw Hill Book Co, New York

Prayitno, Joko Harun, et all. 2000. Pembudayaan Penulisan Karya Ilmiah, Universitas Muhammadiyah Press, Surakarta.

Purbawangsa, Ida Bagus A. 1998. Kajian Kinerja Keuangan Pada Bank Perkreditan Rakyat Di Daerah Tingkat II Badung Propinsi Bali, Tesis Pasca Sarjana Universitas Brawijaya, Malang.

Rahman, Afzalur. 1996. Economic Doctrines of Islam, Jilid 1, Terjemahan Soeroyo, MA, Doktrin Ekonomi Islam, Dana Bhakti Wakaf, Yogyakarta.

1997. Economic Doctrines of Islam, Jilid 2, Terjemahan Soeroyo, MA, Doktrin Ekonomi Islam, Dana Bhakti Wakaf, Yogyakarta. . 1997. Economic Doctrines of Islam, Jilid 3, Terjemahan Soeroyo, MA, Doktrin Ekonomi Islam, Dana Bhakti Wakaf, Yogyakarta. . 1997. Economic Doctrines of Islam, Jilid 4, Terjemahan Soeroyo, MA, Doktrin Ekonomi Islam, Dana Bhakti Wakaf, Yogyakarta.

Rofiq, Ahmad. 2004. Prospek Bank Syariah Meningkat. www. Comment Indonesia,cjb.net

Santoso, Rudy Tri. 1997. Mengenal Dunia Perbankan, Andi Yogyakarta

Setiawati, Lilis, Na'im, Ainun. 2001. Bank Health Evaluation By Bank Indonesia And Earning Management In Banking Industry, Gajah Mada International Journal of Business, Vol. 3. No. 2 
Siamat, Dahlan . 1993.Manajemen Bank Umum, Intermedia, Jakarta.

Singarinbun, Masri dan Efendi, Sofyan. 1995. Metode Penelitian Survey, LP3ES,, Jakarta

Sinkey, JF.1975 . A Multivariate Statistical Analysis of Characteristics of Problem Bank, The Journal of Finance, Vol.XXX, No.1, March, pp.21

Sri Witurachmi. 2000. Analisis Kinerja Keuangan Bank Perkreditan Rakyat Di Wilayah Karesidenan Surakarta, Tesis Pasca Sarjana Universitas Brawijaya, Malang.

Subhash Sharma.1996. Applied Multivariate Techniques, John Willy, New York.

Sumarta, H.Nurmadi. 1999. Evaluasi Kinerja Perusahaan perbankan Yang Terdaftar Di Bursa Efek Jakarta Dan Thailand, Bulletin, Ekonomi Moneter Perbankan, Direktorat Riset Ekonomi \& kebijakan Moneter Bank Indonesia, Vol .3. No.2, September.

Sumitro, Warkun. 1997. Azas-Azas Perbankan Islam dan LembagaLembaga Terkait di Indonesia, Raja wali, Jakarta

Suparmoko.1997. Metode Penelitian Praktis (Untuk Ilmu Sosial dan Ekonomi). Edisi 3, BPFE, Yogyakarta

Sutra Febrian, Erwin. 2004. Bank Syariah dan Bunga. Community for Economic Enlightenment. Jakarta

Umar, Husen. 2000. Research Methods Finance and Banking, Gramedia Pustaka Utama, Jakarta.

Umedi, Usman. 2000. Analisis kinerja Keuangan bank Umum Swasta Nasional Sebelum dan Sesudah Akuisisi, Tesis Paska Sarjana, Universitas Brawijaya, Malang.

Whalen.G dan JB.Thomson. 1988. Using Financial Data Identify Change in Bank Condition, Economic Review, Second Quarter,17-26

Wibowo, Drajat. 2004. Perketat Aturan Kehati-hatian Perbankan Syariah, www. Comment Indonesia,cjb.net 
Witurachmi, Sri. 2000. Analisis Kinerja Keuangan Bank Perkreditan Rakyat di Wilayah Karesidenan Surakarta, Tesis Paska Sarjana Universitas Brawijaya, Malang.

Weston, Fred, dan Eugene F Brigham. 1991. Dasar-Dasar Manajemen Keuangan, Jilid. 2, Erlangga, Jakarta.

Zainul, Arifin. 1999. Memahami Bank Syariah, Alva bet,.Jakarta. 